\title{
Debatable aspects of constructing \\ construction of corpus delicti \\ in the sphere of economic activity \\ (Chapter 22 of the Criminal Code \\ of the Russian Federation)
}

O. G. Solovyev ${ }^{1}$

${ }^{1}$ P. G. Demidov Yaroslavl State University, 14 Sovetskaya str., Yaroslavl 150003,

Russian Federation

DOI: $10.18255 / 1996-5648-2021-4-560-567$

Research article

Full text in Russian

The article analyzes the features of the regulation of crimes in the field of economic activity with formal, material and truncated structures of the compositions in the 1996 Criminal Code of the Russian Federation. The author notes that the presence in Chapter 22 of the Criminal Code of the Russian Federation of a significant number of criminal-legal prohibitions containing a formal type of structure of a crime is criticized in the doctrine of criminal law and does not always meet the rules of criminalization of a socially dangerous act and the needs of law enforcement practice. The absence of signs characterizing the economic consequences (damage, avoidance of losses, etc.) in many dispositions with a formal structure does not allow us to speak of the presence of the level of social danger necessary for criminalization of the illegal behavior of economic entities. A number of crimes, in our opinion, should be legally transferred to the category of administrative offenses.

The author notes that when designing complex alternative compositions, one should carefully select the necessary features with a homogeneous nature and level of public danger. Such alternative signs should be used in a situation where it is impossible to use abstract linguistic terms covering all the signs listed in the disposition. You should also avoid including false signs in alternative constructions of dispositions: repetitive, unreasonable criminologically, intersecting with other elements of crime, etc.

Keywords: criminal liability; crime; economic activity; corpus delicti; classification; formal construction; material construction; truncated construction; complex corpus delicti; crimes; integrated corpus delicti

\section{INFORMATION ABOUT AUTHORS}

\author{
Solovyev, Oleg G. | E-mail: olegsol1961@yandex.ru \\ Cand. Sc. (Jurisprudence), Associate Professor
}

(C) Solovyev O. G., 2021

This is an open access article under the CC BY license (https://creativecommons.org/licenses/by/4.0/) 


\title{
Дискуссионные аспекты конструирования составов преступлений в сфере экономической деятельности (гл. 22 УК РФ)
}

\author{
О. Г. Соловьев ${ }^{1}$
}

${ }^{1}$ Ярославский государственный университет им. П. Г. Демидова, ул. Советская, 14, Ярославль, 150003, Российская Федерация

DOI: $10.18255 / 1996-5648-2021-4-560-567$

УДК 343.337 .4

Научная статья

В статье анализируются особенности регламентации преступлений в сфере экономической деятельности с формальными, материальными и усеченными конструкциями составов в Уголовном кодексе РФ 1996 года. Автор отмечает, что наличие в главе 22 УК РФ значительного количества уголовно-правовых запретов, содержащих формальный тип конструкции состава преступления, критикуется в доктрине уголовного права и не всегда отвечает правилам криминализации общественно-опасного деяния и потребностям правоприменительной практики. Отсутствие признаков, характеризующих экономические последствия (ущерб, избежание убытков и т. д.) во многих диспозициях с формальной конструкцией, не позволяет говорить о наличии необходимого для криминализации уровня общественной опасности противоправного поведения субъектов экономической деятельности. В этой связи ряд преступлений необходимо законодательно перевести в разряд административных проступков.

Автор отмечает, что при конструировании сложных альтернативных составов следует внимательно отбирать необходимые признаки с однородным характером и уровнем общественной опасности. Такие альтернативные признаки следует использовать в основном в ситуации, когда невозможно применять абстрактные лингвистические термины, охватывающие все перечисляемые в диспозиции признаки. Также следует избегать по возможности включения в альтернативные конструкции диспозиций ложные признаки: повторяющиеся, не обоснованные криминологически, пересекающиеся с иными составами преступлений и т. д.

Ключевые слова: уголовная ответственность; преступление; экономическая деятельность; состав преступления; классификация; формальная конструкция; материальная конструкция; усеченная конструкция; сложные составы; интегрированные составы

\section{ИНФОРМАЦИЯ ОБ АВТОРАХ}


В отечественной уголовно-правовой доктрине принято считать, что преступлением с формальной конструкцией состава является такой способ описания деяния, при котором общественно опасные последствия не закрепляются в диспозиции нормы как обязательный признак, поэтому преступление считается оконченным с того момента, когда указанные в законе действия либо уже совершены, либо начали совершаться. Следует сказать, что большая часть деяний в главе 22 УК РФ (Преступления в сфрере экономической деятельности) относятся к преступлениям с формальным составом (их более $65 \%$ от общего числа преступлений в этой главе).

Так, к примеру, к таковым посягательствам возможно отнести: воспрепятствование законной предпринимательской или иной деятельности (ч. 1 ст. 169 УК РФ); регистрацию незаконных сделок с землей (ст. 170 УК РФ); легализацию (отмывание) денежных средств или иного имущества, приобретенных преступным путем (ст. 174, 174.1 УК РФ); нарушение правил изготовления и использования государственных пробирных клейм (ст. 181 УК РФ); незаконный оборот драгоценных металлов, природных драгоценных камней или жемчуга (ст. 191 УК РФ) и ряд других преступлений.

Наличие формальных составов преступлений в главе 22 УК РФ критически оценивается рядом ученых. Так, М. Г. Жилкин и И. А. Тихон говорят о неспособности «формальных» посягательств нанести какой-либо реальный вред охраняемым общественным отношениям [1, с. 236; 2, с. 36]. Полагаем, что данная позиция, в части некоторых преступлений, требует определенной коррекции. Поскольку вред объекту и предмету преступлений в сорере экономической деятельности в большинстве случаев причиняется путем отрицательного воздействия на структурные элементы общественных отношений, такое воздействие может подвергаться криминализации даже без учета возможных последствий. При этом негативное влияние от противоправного поведения может осуществляться не только на один конкретный элемент общественных отношений, но и одновременно на несколько элементов [3, с. 77].

В русле указанной многообъектности заметим, что как материальные, так и формальные составы преступлений бывают простыми и сложными. Простой состав преступления содержит один объект преступного посягательства, одно общественно опасное действие (бездействие), одно последствие, единую форму вины, одну цель или один мотив, которые являются обязательными для квалификации деяния как преступления. В сложном составе представлено несколько объектов преступного посягательства, несколько действий или несколько последствий, или несколько форм вины, мотивов, способов, обязательных для квалификации деяния как преступления. Примером сложного состава служит деяние, закрепленное в ст. 169 УК РФ, в диспозиции которой перечислены несколько альтернативных способов совершения преступления. 
Дискуссионные аспекты конструирования составов...

Разновидностями формального состава преступления выступают усеченные составы и составы создания опасности [4, с. 47]. В преступлениях с конструкцией усеченного состава момент окончания преступления переносится на стадию покушения или приготовления. В составах создания опасности ответственность наступает не в связи с причинением вреда, а в связи с фрактом реальной угрозы его причинения. Примером усеченных составов преступлений в главе 22 УК РФ служит ст. 170.1. УК РФ «Фальсификация единого государственного реестра юридических лиц, реестра владельцев ценных бумаг или системы депозитарного учета». Данное преступление считается оконченным уже с момента предоставления документов, содержащих заведомо ложные сведения. Диспозиция статьи 173.2 УК РФ «Незаконное использование документов для образования (создания, реорганизации) юридического лица» также сконструирована по типу усеченного состава. $\mathfrak{K}$ особенностям конструирования составов преступлений в главе 22 УК РФ можно, несомненно, отнести наличие минимального количества усеченных составов, а также то, что в одном составе одновременно могут быть признаки и материальной и формальной конструкции. Такая конструкция вытекает из указания в ст. 172 УК РФ «Незаконная банковская деятельность» или ст. 178 УК РФ УК РФ «Ограничение конкуренции» на «крупный ущерб» и «крупный доход». Такие нормативные решения включаются в группу формально-материальных составов. Также ряд статей данной главы включают материальные признаки исключительно в квалифицированные составы. К примеру, часть 2 ст. 169 УК РФ «Воспрепятствование законной предпринимательской или иной деятельности» предусматривает такой признак, как причинение крупного ущерба.

Сам фракт наличия такого большого количества преступлений с фрормальным составом в главе 22 УК РФ говорит об избыточности данных конструкций в группе посягательств в сфере экономической деятельности. Нельзя не согласиться с мнением тех ученых, которые говорят о необоснованности регламентации ряда преступлений в главе 22 УК РФ по типу формальных [5, с. $11 ; 6$, с. 70$]$.

Так, например, при конструировании состава ст. 169 УК РФ законодатель не стал включать в данный состав признаки причиненного вреда или мотива виновного. Воспрепятствование законной предпринимательской деятельности влечет уголовную ответственность при наличии самого фракта неправомерного отказа в регистрации индивидуального предпринимателя или коммерческой организации, уклонения от регистрации и т. п. Однако в таком случае стираются, размываются границы уголовной и административной ответственности и нарушаются правила межотраслевой дифференциации. Очевидно, что данное деяние по степени общественной опасности очень часто не выходит за рамки дисциплинарного или административного правонарушения. 
Похожая ситуация складывается и со статьями 170 УК РФ «Регистрация незаконных сделок с недвижимым имуществом» и 181 УК РФ «Нарушение правил изготовления и использования государственных пробирных клейм». Наличие признаков уголовной ответственности за совершение вышеназванных преступлений будет присутствовать лишь в случаях реального наступления значительного либо крупного ущерба или при значительных объемах преступной деятельности (неоднократно, в крупных размерах).

Таким образом, можно сделать вывод, что составы преступлений в сфере экономической деятельности, сконструированные по типу формальных, порой не отвечают требованиям юридической техники и содержат технико-юридические дефекты. В этой связи авторы Концепции модернизации уголовного законодательства в экономической сфере [7] рекомендуют вообще отказаться от конструирования составов экономических преступлений по типу формальных. Полагаем, что эта идея пригодна не ко всем составам преступлений в главе 22 УК РФ (например, для ст. 174, 174.1, 185.5 и др.) [8, с. 179]. Однако для оптимизации норм о преступлениях в сфере экономической деятельности, несомненно, требуется перестройка в виде «материализации» деяния либо его декриминализации для целого ряда формальных, прежде всего основных, составов (ч. 1 ст. 169, ч. 1 ст. 170.1, ч. 2 ст. 170.1 и др.).

Рассмотрим несколько основных классификаций составов преступлений через призму экономических преступлений. По одной из них, производимой в зависимости от структуры закрепленного в уголовном законодательстве состава преступления, выделяются составы простые (т. е. структура которых не усложнена множественностью хотя бы одного признака, относящегося к любому элементу состава преступления, например часть 2 ст. 185.6 УК РФ, предусматривающая ответственность за «умышленное использование инсайдерской информации путем ее неправомерной передачи другому лицу» (если признавать данный состав самостоятельным) и составы сложные (где хотя бы один признак является множественным). Такие составы закреплены в подавляющем количестве норм о преступлениях в сфере экономической деятельности.

Сложные составы преступлений весьма неоднородны, среди них также можно выделить отдельные виды [9, с. 30]. В зависимости от наличия (отсутствия) альтернативных или совмещенных признаков сложные составы преступлений делятся на:

а) альтернативные - составы, включающие 2 или более признака, относящиеся к одному из элементов состава преступления, любого из которых достаточно для обоснования ответственности (квалификации) по этому составу. Примеров подобных составов преступлений в гл. 22 УК РФ довольно много: например, ч. 1 ст. 173.2 УК РФ («Незаконное использование документов для образования (создания, реорганизации) юридического лица») 
описывает несколько альтернативных предметов преступления («документ, удостоверяющий личность», «доверенность»);

б) совмещенные - составы, включающие 2 или более признака, относящиеся к одному из элементов состава преступления, каждый из которых необходим для обоснования ответственности (квалификации) по этому составу. Например, состав преступления, предусмотренный ст. 190 УК РФ («Невозвращение на территорию Российской Федерации культурных ценностей»), предполагает совмещенные признаки, относящиеся к действию («невозвращение», «если такое возвращение обязательно в соответствии с законодательством Российской Федерации»), предмету преступления («культурные ценности», «вывезены за пределы Российской Федерации»);

в) комбинированные - составы с альтернативными и с совмещенными признаками. Например, ч. 3 ст. 200.6 УК РФ («Заведомо ложное экспертное заключение в сфрере закупок товаров, работ, услуг для обеспечения государственных и муниципальных нужд») альтернативна в части субъекта («эксперт», «уполномоченный представитель экспертной организации»), совмещена - в отношении вины (умысел + неосторожность).

В зависимости же от наличия (отсутствия) в конструкции одного состава других составов (или состава) преступлений сложные составы делятся:

а) на интегрированные - составы, которые в своей законодательной конструкции объединяют два и более иных состава преступления. Например, квалифицированный состав, закрепленный в ч. 2 ст. 179 УК РФ («Принуждение к совершению сделки или к отказу от ее совершения») содержит одновременно как основной состав такого преступления, так и в части признака «насилие» - составы преступлений против жизни и здоровья;

б) неинтегрированные, к которым можно отнести, к примеру, ст. 200.1 УК РФ «Контрабанда наличных денежных средств и (или) денежных инструментов» [9, с. 31].

Применительно к каждому из выделенных видов сложных составов преступлений есть свои правила конструирования, пренебрежение которыми зачастую рождает проблемы. Начать стоит с правил конструирования альтернативных составов преступлений. Так, во-первых, альтернативные признаки должны характеризовать однородные по своей природе разновидности криминального поведения. В том числе и по этой причине ст. 183 УК РФ не является базовой для уголовно-правовой охраны всех видов тайны. Под её защиту поставлены коммерческая, налоговая и банковская тайна, но не поставлена, например, государственная - помимо разнородного объекта преступления, государственная тайна обладает и сильно отличающимся от перечисленных видов охраняемой тайны правовым режимом, диктующим необходимость описания в законе других видов противоправного поведения, с другими пределами ответственности.

Во-вторых, альтернативные признаки должны иметь схожий между собой «заряд» общественной опасности [9, с. 32]. С этой точки зрения непра- 
вильным выглядит однопорядковое перечисление в ч. 1 ст. 175 УК РФ заранее не обещанных приобретения и сбыта имущества, заведомо добытого преступным путем - сбыт явно более общественно опасен, чем приобретение.

В-третьих, альтернативные признаки должны употребляться при построении состава преступления тогда, когда при описании не удается подобрать общего понятия для нескольких явлений либо законодатель хочет ограничить запрет лишь несколькими действиями из довольно широкого круга. В связи с этим выглядит необоснованным казуистичное употребление альтернативных признаков тогда, когда запрет можно было бы выразить более абстрактно - примером в гл. 22 УК РФ может служить ч. 1 ст. 185.5 УК РФ, которую можно было бы сорормулировать и без альтернативных признаков - как «совершение незаконных действий (бездействия), направленных на захват управления в юридическом лице».

Проблемой при построении альтернативных составов преступлений является и ложная альтернативность, при которой признаки описываются как альтернативные, но на самом деле один включает в себя другой. Примером может служить ч. 1 ст. 173.1 УК РФ: «представление в орган, осуществляющий государственную регистрацию юридических лиц и индивидуальных предпринимателей, данных, повлекшее внесение в единый государственный реестр юридических лиц сведений о подставных лицах", включает в себя и «образование (создание, реорганизацию) юридического лица через подставных лиц», так как последний из обозначенных процессов не может произойти без передачи данных в орган, осуществляющий государственную регистрацию юридических лиц и индивидуальных предпринимателей.

Применительно к интегрированным составам преступлений чаще всего говорят о необходимости соблюдения следующих правил. Во-первых, конструируя интегративный состав преступления, следует учитывать принцип справедливости и возможности построения санкции, которая бы оптимально ему соответствовала. Например, возвращаясь к уже упоминавшемуся п. «б» ч. 2 ст. 179 УК РФ, можно увидеть, что в случае, если в результате применения такого насилия умышленно причиняется тяжкий вред здоровью, влекущий по неосторожности смерть человека, или же если смерть причиняется умышленно, санкция ч. 2 ст. 179 УК РФ явно недостаточна и требуется квалификация по совокупности преступлений [10, с. 178]. Во-вторых, при построении интегрированных составов необходимо стремиться к унифркации законодательных конструкций. Так, например, в статьях гл. 22 УК РФ признак «насилие» употребляется без разделения на виды (опасное и неопасное).

Таким образом, уголовно-правовая наука выработала довольно четкие и обоснованные правила конструирования сложных составов преступлений в зависимости от их разновидности, которые не всегда соблюдаются законодателем, в том числе и при оформлении гл. 22 УК РФ, что влечет за собой 
появление в теле уголовного закона многочисленных нарывов-дефектов. Исправление этих дефектов на основании научных рекомендаций - одна из основных задач уголовной политики на данный момент.

\section{Ссылки}

1. Ж Жлкин М. Г. О роли оценки в формировании уголовно-правовых понятий // Межвузовский сборник научных трудов адъюнктов и соискателей. Ч. 1: Вопросы совершенствования правоохранительной деятельности органов внутренних дел: М.: Московская академия МВД России, 2001. С. 234-237.

2. Тихон И. А. Некоторые спорные вопросы, возникающие при квалификации преступлений в сфрере экономики // Преемственность и новации в юридической науке: материалы научной конференции адъюнктов и соискателей. Омск: Омская академия МВД, 2005. Вып. 1. С. 37-41.

3. Соловьев О. Г., Гончарова Ю. О. Дискуссионные аспекты определения перечня средств и приемов законодательной техники в правотворческом процессе // Вестник Ярославского государственного университета им. П. Г. Демидова. Серия Гуманитарные науки. 2021. Т. 15, № 1. С. 76-83.

4. Иванчин А. В. Деление составов преступлений по моменту их окончания // Вестник Ярославского государственного университета им. П. Г. Демидова. Серия Гуманитарные науки. 2017. № 4 (42). С. 46-51.

5. Бражник С. Д., Касаткина Н. Н. Лингвистические правила (языковые) правила в законодательной технике // Юридическая наука. 2014. № 3. С. 10-12.

6. Иванчин А. В. Понятие техники построения уголовного законодательства // Дифференциация ответственности и вопросы юридической техники в уголовном праве и процессе: сборник научных статей. Ярославль: ЯрГУ, 2001. С. 63-71.

7. Бавсун М. В., Борков В. Н., Николаев К. Д. Концепция модернизации уголовного законодательства в экономической сфере: критический анализ // Научный вестник Омской академии МВД России. 2011. № 4. URL: https://cyberleninka.ru/article/n/ kontseptsiya-modernizatsii-ugolovnogo-zakonodatelstva-v-ekonomicheskoy-sferekriticheskiy-analiz (дата обращения: 30.08.2021).

8. Грузинская Е. И. Уголовная ответственность за неправомерный захват органов управления юридического лица: вопросы конструирования составов преступлений // Актуальные проблемы гуманитарных и естественных наук. 2016. № 2-3. C. $177-179$.

9. Иванчин А. В. Альтернативные, интегрированные и иные сложные составы преступлений (проблемы трактовки) // Актуальные проблемы уголовного права на современном этапе (вопросы дифференциации ответственности и законодательной техники): сборник научных статей. Ярославль: ЯрГУ, 2012. С. 29-38.

10. Рогова Е. В. Правила построения квалифицирующих и привилегирующих признаков состава преступления // Пробелы в российском законодательстве. 2013. № 5. C. 172-178. 